\title{
PENGARUH COVID-19 DALAM FIKIH IBADAH PERSPEKTIF NEUROSANS: STUDI KASUS SALAT JUM'AT SHAF DISTANCING DI MASJID SUNAN KALIJAGA
}

\author{
Muhammad Hisyam Fathin \\ Universitas Ahmad Dahlan \\ Email: Muhammad1900031303@webmail.uad.ac.id \\ Suyadi \\ Universitas Ahmad Dahlan \\ Email: suyadi@fai.uad.ac.id
}

\begin{abstract}
In March 2020 there was a lockdown in mosques in Indonesia and there were some mosques who still allowed their congregation to pray at the mosque by imposing distance shafts, because recently in the world even in Indonesia was hit by a disaster in the form of COVID-19 virus or COVID-19 virus. The government in Indonesia is taking fast response actions in dealing with the spread of the COVID-19 virus, by applying social distancing, using masks when outside the home, in terms of worship also applies distance prayers in areas that are still safe while in areas that already suffer from COVID-19 to pray pilgrims at their respective homes, this is done in order to prevent the spread of COVID-19 that occurred in Indonesia. The aim is to analyze the effect of COVID-19 on the procedure for conducting prayers through online observation methods and other online news, the results of the study show that after the COVID-19 occurrence some scholars believe that the procedure for conducting congregational prayers at the mosque may be done within a distance of one congregation with worshipers others one meter or less away in that area with COVID-19 transmission are still few.
\end{abstract}

Keywords: Lockdown Masjid, Fiqh of Worship, Neuroscience.

\begin{abstract}
Abstrak
Pada bulan Maret Tahun 2020 terjadinya lockdown di masjid-masjid di Indonesia dan ada beberapa masjid yang masih membolehkan jama'ahnya untuk sholat di masjid dengan memberlakukan shaf berjarak, karena baru-baru ini di dunia bahkan di Indonesia sedang terkena musibah berupa virus COVID-19 atau virus COVID-19. Pemerintah di Indonesia melakukan aksi cepat tanggap dalam menangani penyebaran virus COVID-19 ini, dengan memberlakukan social distancing, menggunakan masker saat diluar rumah, dalam hal ibadah pun memberlakukan sholat berjarak di daerah yang masih aman sedangkan di daerah yang sudah banyak yang menderita COVID19 melakukan sholat jamaah dirumah masing-masing, ini dilakukan guna pencegahan
\end{abstract}

Nur El-Islam, Volume 7, Nomor 2, Oktober 2020 
penyebaran COVID-19 yang terjadi diindonesia.Tujuannya menganalisis pengaruh COVID-19 terhadap tata cara pelaksanaan ibadah sholat melalui metode observasi online dan berita online lainnya, hasil penelitian menunjukkan bahwa setelah terjadinya COVID-19 beberapa ulama berpendapat bahwasanya tata cara pelaksanaan sholat jamaah di masjid boleh dilakukan dengan berjarak antara satu jamaah dengan jamaah yang lain sejauh satu meter atau kurang dari itu di daerah yang penularan COVID-19 masih sedikit

Kata kunci: Masjid Lockdown, Fikih Ibadah, Neurosains.

\section{A. Pendahuluan}

Indonesia sebagai negara dengan penduduk Islam terbesar dunia ${ }^{1}$ merupakan negara paling terdampak COVID-19 di Asia Tenggara. ${ }^{2}$ Hal ini dibuktikan dengan jumlah kasus positif yang mencapai 927.380 dan meninggal dunia sebanyak 26.590 jiwa pada Januari 2021. Oleh karena itu, mitigasi COVID-19 di Indonesia perlu menggunakan pendekatan agama dan sains sekaligus. ${ }^{3}$ Padahal, sejak Maret tahun 2020 Indonesia melakukan lockdown yang terjadi di masjid-masjid daerah yang mengalami dampak penularan COVID-19, karena penyakit COVID-19 ini tidak bisa dianggap remeh, virus ini telah memakan banyak korban mulai dari yang muda sampai tua semuanya dapat terkena virus COVID-19. ${ }^{4}$ COVID-19 dapat menyebabkan kematian, di seluruh dunia sudah banyak yang meninggal karena virus ini. Di Indonesia sendiri pemerintah mengambil tindakan pencegahan penyebaran COVID-19 dengan memberlakukan social distancing, tidak keluar rumah apabila tidak ada

${ }^{1}$ Suyadi, “Mainstreaming The Knowledge of Islamic Education With Progress and of Islam Nusantara Education," Akademika, vol. 24, no. 1, 2019, h. 37-66.

${ }^{2}$ Suyadi; Z Nuryana; N A Febriana, "The Fiqh of Disaster: The Mitigation of Covid-19 in the Perspective of Islamic Education-Neuroscience," International Journal of Disaster Risk Reduction IJDRR_2020 (2020): Article Inpress. Published online 2020 Sep 15. doi: $10.1016 /$ j.ijdrr.2020.101848

${ }^{3}$ Suyadi and Sutrisno, “A Genealogycal Study of Islamic Education Science at the Faculty of Ilmu Tarbiyah Dan Keguruan UIN Sunan Kalijaga,” Al-Jami'ah, vol. 56, no. 1, h. 29-58,

${ }^{4}$ L Mutakinati A Abidah, H N Hidaayatullaah, R M Simamora, D Fehabutar, "The Impact of COVID-19 to Indonesian Education and Its Relation to the Philosophy of "Merdeka Belajar," Studies in Philosophy of Science and Education, vol. 1, no. 1, h. 38-49. 
kepentingan, menggunakan masker ketika keluar rumah, mencuci tangan dengan sabun/ hand satilizer. ${ }^{5}$ Dengan pendekatan saintifik ini, pencegahan dapat memperkecil terjadinya penularan COVID-19.

Dalam hal ibadah sendiri, di dunia bahkan di Indonesia ketika pertama kali terjadinya wabah COVID-19 mulai di lakukan sholat dengan jarak shaf dari satu orang ke orang lain dengan jarak 1 meter, ini dilakukan karena melihat virus COVID-19 ini dapat menular apabila percikan air ludah (droplet) orang yang sakit dengan orang yang sehat. ${ }^{6}$ Dalam mengambil tindakan pencegahan para ulama memutuskan untuk sholat dengan jarak 1 meter, walaupun seperti ini tapi di daerah yang mayoritas penduduknya telah terinfeksi maka untuk sholat berjamah dilakukan di rumah masing- masing, dan untuk sholat berjarak hanya berlaku pada daerah yang masih belum ada yang terinfeksi virus ini.

Di zaman modern saat ini, pergerakan non-stop manusia dan barang menyebabkan tidak ada negara yang kebal terhadap penyakit endemik (penyakit menular yang berjangkit dengan cepat di daerah yang luas dan menimbulkan banyak korban). Desember 2019, terdapat sejumlah kasus pneumonia yang sering ditemukan dengan penyebab belum diketahui dan memiliki ciri-ciri: gejala demam, rasa letih, batuk, dan kesulitan bernafas sebagai gejala utama. Penyakit ini muncul pertama kali di Wuhan, Pemerintah dan depertemen kesahatan di semua tingkat memberikan prioritas utama terhadap penyakit ini dan segera memberlakukan tindakan untuk perawatan medis dan pengendalian penyakit, dan mengarahkan penelitian untuk melakukan investigasi. Pneunomia yang di sebabkan oleh infeksi virus ini disebut pneumonia COVID-19 virus baru (COVID-19) oleh WHO.

Dampak COVID-19 terhadpa perubahan ibadah terutama shaf dalam salat yang semula rapat menjadi berjarak penting dikaji dalam perspektif neurosains. Neurosains merupakan ilmu tentang otak yang

${ }^{5}$ BNPB, “Satuan Tugas Percepatan COVID-19 Indonesia,” Pemerintah Republik Indonesia, 2020. 
mempelajari perilaku, ${ }^{7}$ termasuk perilaku beragama dintengah pandemi COVID-19. Majelis Ulama Indonesia (MUI) telah mengeluarkan fatwa tetang pencegahan COVID-19, salah satunya adalah mengubah shaf dalam salat yang semula rapat menjadi berjarak. Perubahan ini tidak serta merta diterima, melainkan hanya merekan yang cara berpikirnya sehat saja megikuti fatwa tersebut. ${ }^{8}$ Oleh karena itu, perlu upaya edukasi perubahan perilaku beragama denga pendekatan neurosains. ${ }^{9}$ Pendekatan ini diperlukan karena COVID-19 perlu masih banyak umat Islam yang bersikap "anti-sains" 10 dalam beragama di tengah darurat COVID-19. ${ }^{11}$

Metode pendekatan penelitian ini dilakukan melalui kualitatif dalam observasi online. Sumber data penelitian melalui proses literatur baik yang berasal dari buku maupun jurnal di bidang Pendidikan Islam, neurosains, dan berita terkait COVID-19. Pengumpulan data dilakukan dengan cara menelusuri referensi terkait, baik secara manual ataupun digital. Data-data yang terkumpul kemudian dipelajari, dikurangi, dan dibangun kembali menjadi konsep baru yang utuh dan fresh (segar). Dengan dibuatnya penelitian ini dapat menambah wawasan terkait dengan hukum sholat berjarak,

${ }^{7}$ Suyadi, Teori Pembelajaran Anak Usia Dini Dalam Kajian Neurosains (Bandung: Remaja Rosdakarya, 2016), http://www.bukukita.com/Orang-Tua-danKeluarga/Psikologi- \&-Pendidikan-Anak/129444-Teori-Pembelajaran-Anak-usia-DiniDalam-Kajian-Neurosains.html.

${ }^{8}$ Suyadi, "Pendidikan Islam Anak Usia Dini Dalam Perspektif Neurosains: Robotik Akademik Dan Saintifik,” Edukasia: Jurnal Penelitian Pendidikan Islam, vol. 13, no. 2, h. 231-62.

${ }^{9}$ Suyadi, “The Synergy of Arts, Neuroscience, and Islam in Early Childhood Learning in Yogyakarta," TARBIYA: Journal of Education in Muslim Society, vol. 5, no. 1, h. 30-42.

${ }^{10}$ Suyadi Suyadi, "Integration of Anti-Corruption Education (PAK) In Islamic Religious Education (PAI) With Neuroscience Approach (Multi-Case Study in Brain Friendly PAUD: I Sleman Kindergarten Yogyakarta)," Inferensi: Jurnal Penelitian Sosial Keagamaan, vol. 12, no. 2, h. 307-30.

${ }^{11}$ Suyadi, Pendidikan Islam Dan Neurosains: Menelusuri Jejak Akal Dan Otak Dalam Al-Qur'an Hingg Pengembangan Neurosains Dalam Pendidikan Islam (Jakarta: Kencana, 2020). 
sehingga tidak memunculkan rasa yang paling benar dalam ibadahnya dan menggangap yang melaksanakan sholat berjarak sebagai bida'ah.

\section{B. Pembahasan}

Dilihat dari sejarahnya, di tahun 1960 virus COVID-19 pertama kali diketahui sebagai penyebab flu biasa di tahun 2002, virus ini masih belum membahayakan manusia. Namun setelah terjadinya Severe Acute Respiratory Syndrome (SARS Cov) di China, sehingga para ilmuan mulai berpusat pada wabah yang sedang terjadi dan mendapatkan bahwa pandemi yang sedang terjadi ini merupakan bentuk baru dari COVID-19. Di tahun 2012, di Timur Tengah terjadi pandemi yang serupa yaitu Middle East Respiratory Syndrome (MERSCov). ${ }^{12}$ Dari kedua kasus tersebut dapat dilihat mengenai penyakit ini bukan merupakan virus yang konstan bahkan berpeluang menyesuaikan diri dan berprofesi lebih ganas, sehingga berpeluang merenggut nyawa seseorang. Mulai saat itu, observasi yang dilakukan menjadi lebih maju.

Sebenarnya virus COVID-19 sudah ada sejak dahulu kala, virus ini dapat menginfeksi manusia maupun terhadap hewan. Contohnya unggas, kelewar, anjing, dan hewan lainnya, begitu juga terjadi terhadap manusia. Virus COVID-19 model baru atau bisa disebut Novel COVID-19 Virus ( 2019-nCoV) yang sekarang sedang meningkat, bukan merupakan sesuatu yang baru, melainkan merupakan hasil dari alterasi. Virus Novel COVID-19 Virus (COVID-19) ini memiliki kesamaan dengan penyakit yang menjadi penyebab terjadinya SARSCov dan MERS-Cov. COVID-19 virus memiliki ukuran kecil yaitu (berdiameter 65-125 nm) dan mengandung RNA untai tunggal sebagai bahan nukleat, memiliki ukuran berkisar antara 26 hingga $32 \mathrm{~kb}$.

12 Ahmed Al-mandhari et al., “COVID-19virus Disease 2019 Outbreak: Preparedness and Readiness of Countries in the Eastern Mediterranean Region," East Mediterr Health Journal, vol. 26, no. 2, h. 136-37. 
Keluarga COVID-19virus dibagi menjadi beberapa kelompok yaitu alfa (a), beta (b), gamma (c), dan delta (d). ${ }^{13}$

COVID-19 adalah penyakit aktual yang dapat mengakibatkan gangguan pernapasan dan radang paru. Penyakit ini terjadi karena infeksi Severe Acute Respiratory Syndrome COVID-19 virus 2 (SARS-Cov2). ${ }^{14}$ Gejala klinis yang muncul bervariasi, mulai dari seperti gejala flu biasa (batuk, pilek, nyeri tengorokan, nyeri otot, nyeri kepala) sampai berkomplikasi berat (pneumonia, atau sepsis). COVID-19 pertama kali diidentifikasi di Wuhan, Cina ${ }^{15}$, pada bulan Desember 2019 dan kemudian dikonfirmasi sebagai virus COVID-19 baru pada 7 Januari 2020 kasus-kasus awal telah dikaitkan ke pasar makanan laut langsung di Wuhan, Cina, dan sember hewan tertentu belum ditentukan, di antara sekelompok pasien yang ada di sajikan dengan bentuk pneumonia virus yang tidak di kenal dengan memiliki sejarah bersama mengunjungi pasar makanan laut Huanan. Pasien di nilai untuk pneumonia virus melalui penetapan dan pengujian cairan broncholveolarlavage memanfaatkan sekuensing genom keseluruhan, kultur sel dan reaksi berantai polymerase (PCR). ${ }^{16}$ Virus ini diisolasi dari sampel biologis dan di identifikasi sebagai genus betaCOVID19virus, menempatkannya di samping Sindrom Akut Parah lainnya (SARS) dan Sindrom Pernafasan Timur Tengah (MERS). ${ }^{17}$

Deteksi virus baru ini pada manusia tanpa mengetahui sumber infeksi telah meningkatkan rasa kekhawatiran yang tidak hanya di

${ }^{13}$ Muhammad Adnan et al., “COVID-19 Infection : Origin , Transmission , and Characteristics of Human COVID-19viruses," Journal of Advanced Research, vol. 24, h. 9198.

${ }^{14}$ Peng Li et al., "Transmission of COVID-19 in the Terminal Stage of Incubation Period: A Familial Cluster,” Journal of Infectious Diseases, 2020.

${ }^{15}$ Chunwen Xu et al., "The 2019-NCoV Epidemic Control Strategies and Future Challenges of Building Healthy Smart Cities,” 2020.

${ }^{16}$ Noah C Peeri et al., "The SARS, MERS and Novel COVID-19virus (COVID-19) Epidemics, the Newest and Biggest Global Health Threats: What Lessons Have We Learned?," Journal of Epidemiology 0, no. 0, h. 1-10, https://doi.org/10.1093/ije/dyaa033.

${ }^{17}$ Mazin Barry, Maha Al Amri, and Ziad A Memish, "COVID-19 in the Shadows of Mers-CoV in the Kingdom of Saudi Arabia," Journal of Epidemiology and Global Health, vol. 10 , no. 1 , h. $1-3$. 
Cina, tetapi juga secara internasional. Hingga saat ini, wabah telah menyebar ke sebagian besar provinsi di Cina dan menyebar luas ke beberapa negara lainnya dalam waktu yang relatif singkat. Sejauh ini, jumlah kasus yang dikonfirmasi dan kematian terkait dengan wabah penyakit COVID-19 virus telah melampaui keseluruhan kasus dan kematian akibat epidemic SARS. Ketika situasi berkembang, banyak detail mengenai profil epidemologi Penyakit COVID-19 virus 2019 (COVID-19) belum dijelaskan. Informasi terkini menunjukkan bahwa kasus muncul dengan gejala penyakit pernafasan akut, seperti batuk, demam, dan kesulitan bernafas, dan gejala ini berkisar dari ringan hingga berat. ${ }^{18}$

\section{COVID-19 Perspektif Neurosains Pendidikan Islam}

Pandemi Covid-19 semenjak bulan Desember 2019, sampai saat ini belum ada tanda akan berakhir. Pada awal pandemi, masyarakat merasakan aroma kekhawatiran dan cenderung ketakutan, namun setelah 1 tahun pandemi Covid-19 berlansung, masyarakat khususnya generasi milenial ${ }^{19}$ cenderung menganggap biasa bahkan menjadi abai terhadap protokol kesehatan. Munculnya claster baru yang diakibatkan kegiatan keagamaan yang tidak mematuhi protokol kesehatan menjadi salah satu naiknya jumlah pasien COVID-19 yang terjadi di Indonesia, seperti ada beberapa pemuka agama mengadakan suatu acara yang mendatangkan kerumunan masa. ${ }^{20}$ Maka inilah yang perlu disadari bahwa sebagai pemuka agama hendaknya ikut serta mengedukasi masyarakat akan bahaya Covid-19, dan bisa menjadi contoh orang yang patuh terhadap protocol kesehatan.

${ }^{18}$ Summer Chavez et al., “American Journal of Emergency Medicine COVID19virus Disease ( COVID-19 ): A Primer for Emergency Physicians," American Journal of Emergency Medicine, 2020, https://doi.org/10.1016/j.ajem.2020.03.036.

${ }^{19}$ Suyadi and Hendro Widodo, "Millennialization of Islamic Education Based on Neuroscience in The Third Generation University in Yogyakarta Indonesia," Qudus International Journal of Islamic Studies , vol. 7, no. 1, h. 173-202.

${ }^{20}$ Suyadi, "Diferensiasi Otak Laki-Laki Dan Perempuan Guru Taman KanakKanak Aisyiyah Nyai Ahmad Dahlan Yogyakarta: Studi Pendidikan Islam Anak Usia Dini Perspektif Gender Dan Neurosains," Sawwa: Jurnal Studi Gender, vol. 13, no. 2, h. 179202. 
Sejak munculnya COVID-19 di Indonesia yang mayoritas penduduknya beragama, ada segelintir masyarakat yang sikapnya “antisains” dan beranggapan bahwa hanya dengan ritual-ritual keagamaan dapat menghindari dari virus ini. Merasa kebal corona hanya dengan berdoa. Ketika masjid ditutup mereka melakukan propaganda, melawan protokol kesehatan karena dianggap menghalangi masuk surga. Sehingga agama yang seharusnya menjadi potensi besar dalam mencegah COVID-19 justru menjadikan klaster terbaru penyebaran COVID-19 di Indonesia.

Dalam hal ini konsep neurosains, ${ }^{21}$ khususnya akal bertingkat ${ }^{22}$ dapat menjadi acuan bagi mitigasi dan edukasi perubahan perilaku beragama di tengah darurat COVID-19. ${ }^{23}$ Oleh karena itu, perlu tahapan edukasi dalam mengubah perilaku beragama, ${ }^{24}$ mulai dari ikhtiar yang paling sederhana hingga upaya dengan pendekatan saintifik sebagaimana direkomendasikan oleh Satgas COVID-19. ${ }^{25} \mathrm{Hal}$ ini menunjukkan bahwa berdoa saja dapat terhindar dari Covid19, tetapi perlu adanya tindakan nyata untuk mencegah penyebaran. Sebagai langkah dalam mencegah penularan COVID-19, sholat berjarak lebih dianjurkan daripada sholat secara rapat. Walaupun tidak ada dalil tentang sholat secara berjarak namun dilihat dari kemaslahatan murshalah, sehingga menjadikan sholat berjarak menjadi dianjurkan.

${ }^{21}$ Suyadi Suyadi, "Hybridization of Islamic Education and Neuroscience: Transdisciplinary Studies of 'Aql in the Quran and the Brain in Neuroscience," Dinamika Ilmu, vol. 19, no. 2, h. 237-49.

${ }^{22}$ Suyadi Kharisma Noor Latifatul Mahmudah, "Akal Bertingkat Ibnu Sina Dan Taksonomi Bloom Dalam Pendidikan Islam Perspektif Neurosains,” Edukasia Islamica: Jurnal Pendidikan Islam vol. 5, no. 1, h. 121-38.

${ }^{23}$ Suyadi, “Kisah (Storytelling) Pada Pembelajaran Anak Usia Dini Dalam Kajian Neurosains Pendidikan Islam," Jurnal Ilmiah Islam Futura, vol. 18, no. 1, h. 52-74.

${ }^{24}$ Astuti Budi Handayani and Suyadi Suyadi, "Relevansi Konsep Akal Bertingkat Ibnu Sina Dalam Pendidikan Islam Di Era Milenial, Ta'dibuna," Jurnal Pendidikan Islam, vol. 8, 2019, https://doi.org/10.32832/Tadibuna.V8I2.2034.

${ }^{25}$ Suyadi, "Konsep Akal Bertingkat Al-Farabi Dalam Teori Neurosains Dan Relevansinya Dengan Pendidikan Islam," Tawazun: Jurnal Pendidikan Islam, vol. 13, no. 1, h. 1-17. 


\section{Dampak COVID-19}

Virus COVID-19 yang telah menjadi pandemic global membawa dampak signifikan dalam perubahan dunia. Sejumlah aspek mulai dari ekonomi, transportasi, hingga kehidupan sehari- hari, nyaris tidak ada yang bisa berkelit dari serangan virus yang diberi nama resmi SARSCOV -2 ini. Semakin banyaknya jumlah pasien yang ada menyebabkan tenaga medis yang ada kewalahan dan rumah sakit menjadi sesak karenanya. Bertambahnya jumlah pasien Covid-19 tenaga medis yang ada mengalami gangguan psikologi karena berkurangnya waktu istirahatnya dan mulai berkurangnya ruangan dan obat- obatan yang ada. $^{26}$

Menyebarnya virus di Indonesia sendiri membawa efek negatif bagi Indonesia, lebih-lebih dalam segi perekonomian. Pemerintah di Indonesia sendiri masih menggunakan pola pikir economic developmentalist, dengan mengorbankan situasi darurat kesehatan global. ${ }^{27}$ Setelah melihat ketidaksiapan pemerintah Indonesia yang malah bersikap santai sebelum kasus pertama COVID- 19 dikonfirmasi, pengumuman yang diumumkan Presiden Jokowi pada 2 maret diharapkan akan menjadikan satu pikiran para pejabat pemerintah dalam menghadapi kenyataan pahit ini. Diharapkan dengan adanya pengumuman tersebut akan melakukan tindakan bersama dan menghadirkan pendekatan yang lebih terkoordinasi, responsif, dan komprehensif. Sayangnya tidak demikian, hingga saat ini tidak ada harapan yang terwujud.

Wabah COVID-19 sangat berdampak dalam sisi perekonomian di Indonesia. Tidak terkecuali dalam pembuatan perlengkapan APD saja yang terhambat, juga terhalangnya pendanaan. Disisi lain, Badan Pusat Statistik (BPS) mendata jumlah turis dari berbagai negara di Januari 2020 sejumlah satu koma dua puluh tujuh juta orang, mengalami penurunan sebesar 7,62 \% dibandingkan Desember 2019. Selama dalam kurun waktu yang serupa di 2019, mendapati ekskalasi

${ }^{26}$ Li Yang and Zhang Lian-yang, “识》解读” vol. 45, no. 2, h. 113-17.

${ }^{27}$ A Ibrahim Almuttaqi, Menteri Kesehatan, and Republik Indonesia, "Kekacauan Respons Terhadap COVID-19 Di Indonesia,” no. 13, 2020. 
5,85 \%. Turis yang berkunjung ke Indonesia dipengaruhi oleh penduduk yang berasal dari Malaysia dengan jumlah 206 ribu orang atau 16,2 \%. Di urutan kedua yaitu wisman yang berasal dari China sejumlah seratus delapan puluh satu ribu orang atau 14,0\%. Selanjutnya diikuti turis dari negara Singapura dengan jumlah 138,6 ribu orang atau 10,9\%, turis dari negara Australia dengan kisaran 117,3 ribu atau 9,2 \% dan turis Timur Leste sejumlah 110,4 ribu orang atau $8,7 \%$. Dan selebihnya dari berbagai negara dengan jumlah sebanyak 528 ribu orang atau 40,7\%.

Dampak lainnya adalah negara Arab Saudi mengistirahatkan akseptasi rombongan yang hendak umrah dari berbagai negara dalam selang waktu tertentu, salah satunya Negara Indonesia. Hal ini merupakan strategi pencegahan dalam upaya pencegahan penyakit ini yang sedang terjadi di penjuru dunia. Sehingga, Kedaulatan Indonesia secara formal membatalkan dalam kurun waktu tertentu jamaahnya yang akan ibadah di tanah suci. Tercatat dengan jumlah 4.078 jamaah dipastikan tertunda keberangkatan ke tanah suci. Terdapat 1.685 jamaah yang terbengkalai di negara perpindahan, yang sedang dalam prosedur pengembalian ke tanah lahir. Jamaah yang tertunda keberangkatannya itu bersumber dari tujuh puluh lima Penyelenggaraan Perjalanan Ibadah Umrah (PPIU) yang rencananya hendak dibawa dengan delapan perusahaan penerbangan.

Dampak dari COVID-19 juga mengakibatkan sejumlah materi seperti masker sulit dicari dan dijual dengan harga yang relatif tinggi. Setelah menyebarnya pandemi ini masker mulai diburu oleh para penduduk. Kuantitas pesanan menyebabkan stock menjadi lebih sedikit serta menjadikan harga melambung. Dibicarakan, yang pertama kali hilang dari pasaran yaitu masker biasa .Belakangan, harganya melambung cukup tinggi di kisaran Rp 60 ribu - Rp 80 ribu per boksnya tapi masih menjadi buruan warga. Selain masker, tarif hand santizer biasa disebut dengan cairan antiseptic pun menghadapi ekskalasi dari Rp 160.000/botol menjadi Rp 180 ribu. Warga juga dibatasi dalam pembelian hand santizer yaitu maksimal membeli hanya dua botol karena menghindari aksi penimbunan. 


\section{Mitigasi COVID-19}

Seiring bejalannya waktu ada beberapa negara yang berhasil menurunkan perkembangan pandemik Covid- 19 secara signifikan, diantaranya Cina dan Korea Selatan. Secara umum ada tiga metode untuk mengatasi pandemik COVID-19 ini yaitu isolasi atau karantina, pengujian massal dan herd immunity. Biasanya pemerintahan resmi menjalankan yang pertama dan yang kedua secara besamaan, dengan memaksimalkan salah satunya. Untuk cara yang ketiga relatif sangat lambat dan resikonya sangat besar karena akan memakan banyak korban. Herd immunity sendiri terbagi menjadi dua yaitu herd immunity alamiah dan herd immunity buatan. Metode ini didapatkan dari kasuskasus pandemik terdahulu, yang menggunakan prinsip seleksi alam.

Covid- 19 termasuk dalam model virus yang tergolong baru mengakibatkan banyak orang yang belum tahu dan belum mengetahui bagaimana cara menghadapi virus tersebut. Sehingga di Indonesia sendiri Pemerintah Republik Indonesia membuat protokol kesehatan. Protokol ini akan diterapkan di seluruh Indonesia oleh pemerintah dengan panduan terpusat oleh Kementerian Kesehatan RI ${ }^{28}$. Pada awalnya pemerintahan di Indonesia ini tidak ingin menyebarkan informasi ke masyarakat terkait virus COVID-19 yang masuk ke Indonesia. Hal ini dikerjakan supaya tidak terjadinya keresahan pada warga Indonesia.

Infeksi terkait rumah sakit adalah salah satu indikator perawatan berkualitas dan keselamatan pasien, Meskipun resiko infeksi tersebar dimana-mana, tapi rumah sakit merupakan daerah yang memiliki resiko tinggi. Untuk setiap 100 pasien yang dirawat di rumah sakit, survei di beberapa negara berkembang terkena infeksi terkait rumah sakit, pengendalian infeksi adalah tanggung jawab semua karyawan rumah sakit. Pengetahuan dalam pengendalian infeksi adalah elemen kunci dalam memutus rantai infeksi. ${ }^{29}$ Sampai akhirnya pemerintahan

${ }^{28}$ Dalinama Telaumbanua, “Urgensi Pembentukan Aturan Terkait Pencegahan COVID-19 Di Indonesia,” Jurnal Pendidikan, Sosial, Dan Agama, vol. 12, no. 1, h. 59-70.

${ }^{29}$ Anil K Bhat Latha T, “Compliance Towards Infection Prevention and Control Practices in Orthopedic Department of a Tertiary Care Hospital .," Journal of Health and Allied Sciences, vol. 18, no. 9, h. 11-14. 
membuat beberapa upaya pencegahan virus COVID-19 sebagai berikut:

\section{a. Social Distancing}

Social distancing menjadi salah satu kata kunci yang akhir-akhir ini sering kita temui dalam upaya menghadi virus COVID-19 yang sedang mendunia. Social distancing adalah upaya yang dilakukan untuk mengurangi interaksi social dalam periode tertentu. Hal ini bukan berarti kita hidup dalam isolasi total, tapi setiap orang diharapkan bisa menyelesaikan interaksi mana yang benar- benar harus dilakukan dan mana yang bisa dikerjakan tanpa melalui kontak langsung. Suatu individu juga mempunyai alasan yang kuat untuk tidak lepas dari suatu pertukaran social. ${ }^{30}$ Penerapan kegiatan social distancing yang diterapkan masyarakat dapat memperlambat penyebaran COVID-19.

Pemerintah telah mengeluarkan imbauan untuk social distancing, antara lain dengan meminta sekolah dan perusahaan melakukan kegiatan pokok sehari- hari melalui jaringan internet dan dilakukan dengan online. Dalam hal pembelajaran anak didik, belajar dapat diartikan perubahan tingkah laku pada diri individu berkat interaksi antara individu dengan individu lainnya dan individu dengan lingkungannya, sehingga mereka dapat berinteraksi dengan baik, ${ }^{31}$ dalam hal ini diharapkan dengan dilakukannya daring atau belajar online dapat membentuk kepribadian yang baik. Dengan dilakukannya social distancing diharapkan tidak terjadinya sikap prasangka dapat mempengaruhi terjadinya diskriminsi, ${ }^{32}$ karena dapat menjadikan terjadinya interaksi sosial yang tidak berjalan sesuai dengan apa yang diharapkan. Saat berlangsungnya periode social distancing kita diminta

${ }^{30}$ George A. Akerlof, "Social Distance and Social Decisions Author ( s ): George A

Akerlof Published by: The Econometric Society Stable URL: Https://Www.Jstor.Org/Stable/2171877 to Econometrica," Jurnal of The Econometric Society, vol. 65, no. 5, h. 1005-27.

${ }^{31}$ Abdul Malik, "Fungsi Komunikasi Antara Guru Dan Siswa Dalam Meningkatkan Kualitas Pendidikan ( Studi Kasus Proses Belajar Mengajar Pada SMP Negeri 3 Sindue ),” Jurnal Interaksi, vol. 3, no. 2, h. 168-73.

${ }^{32}$ Patrick W Corrigan et al., "Prejudice , Social Distance , and Familiarity with Mental Illness,” Schizophrenia Bulletin, vol. 27, no. 2, h. 219-26. 
untuk jaga jarak 1 meter dan untuk mengurangi perkumpulan yang ada.

\section{b. Masjid Lockdown}

Berdasarkan bahasa Inggris lockdown artinya kuncian, maksudnya adalah negara yang telah terkontaminasi virus Covid- 19 mengunci kasus keluar masuknya sebagai upaya pengamanan ketat untuk mencegah penyebar luasan COVID-19. Gubernur DKI Jakarta telah memberikan kebijakan berlandaskan nomor 5 tahun 2020 yang berkaitan dengan Peniadaan Sementara Kegiatan Peribadatan dan Keagamaan Di Rumah Dalam Rangka Mencegah Penyebaran Wabah COVID-19 virus desease ${ }^{33}$. Dalam hal ini pemerintahan menyampaikan peniadaan kegiatan peribadatan yang mengumpulkan banyak orang yang dilaksanakan di masjid, di antaranya ibadah shalat jum'at, majelis taklim, perayaan hari besar dan lain- lainnya. Kemudian disiapkan dan disampaikan paduan bagi penyelenggaraan ibadah agar melaksankan ibadah di rumah sebagai pengganti kegiatan yang ditiadakan. Terkait kebijakan lockdown, sebenarnya juga sudah diatur dalam undang-undang Nomor 6 Tahun 2018 tentang Karantina Kesehatan.

\section{c. Menggunakan Masker}

Salah satu cara pencegahan penularan COVID-19 adalah menggunakan masker. Masker merupakan salah satu alat perlindungan diri yang dapat menghalangi tubuh dari polusi udara. Penggunaan masker juga sudah menjadi salah satu upaya pencegahan primer dari berbagai resiko penyakit yang tersebar lewat partikelpartikel di udara. Masker itu efektif, karena penggunaan masker bertujuan untuk memblokir 'pembawa' yang menularkan virus pernapasan meliputi kontak dekat dalam jangka pendek dan transmisi bersin dari pasien jarak jauh ${ }^{34}$. Keefektifan masker untuk melindungi dari risiko penyebaran virus telah dibuktikan dalam sebuah penelitian

${ }^{33}$ Nur Rohim Yunus et al., “Kebijakan Pemberlakuan Lockdown Sebagai Antisipasi Penyebaran COVID-19 Virus COVID-19,” Jurnal Sosial\&Budaya Syar-I 7, no. 3, h. 211-82.

${ }^{34}$ Editor-in-chief Wang Zhou, The Covid-19 virus Prevention Handbook, (Wuhan: Hubei Science and Technology Press, 2020). 
yang dipublukasikan pada International Journal of Infectious Disease. Penelitian tersebut menemukan bahwa dalam penggunaan masker yang benar bisa menurunkan risiko terkenanya penyakit seperti flu sebanyak 80\% lebih rendah. Dengan mendunianya Novel COVID-19 virus akhir- akhir ini, masyarakat seakan diingatkan kembali akan pentingnya menggunakan masker saat bepergian untuk memperkecil terinfeksinya penyakit.

Jika kita berpapasan dengan sesorang yang terkontaminasi, masker mampu mencegah peluang terjangkit dari penyakit tersebut. Seandainya seseorang mendapati tanda-tanda yang mengacu pada virus COVID-19 atau telah didiagnosis, memakai masker mampu melindungi orang lain. Untuk masker yang digunakan untuk mencegah penularan covid- 19 hanya beberapa jenis masker tertentu. Pakar penyakit menular dari Vanderbilt University in Tennessee, Wlliam Schaffner mengatakan bahwa masker bedah merupakan masker yang kurang efektif dalam mengatasi virus COVID-19 tapi dapat meminimlisir terjadinya penularan. Adapun beberapa jenis masker untuk mengurangi risiko penularan COVID-19 Covid- 19 diantaranya adalah Masker N95 masker ini adalah masker yang sering ditemukan ketika pandemic COVID-19 atau Covid- 19.

Masker ini sangat dianjurkan dalam penggunaannya sebagai upaya pencegahan penyebaran virus COVID-19, Masker gas yang digunakan sebagai pelindung diri dari gas dan uap yang berbahaya tapi juga efektif digunakan untuk pencegahan penyebaran virus COVID-19 atau Covid- 19 karena masker ini memiliki filter yang tepat untuk bahan kimia tertentu, Masker N99 termasuk jenis masker yang efektif untuk melindungi dari populasi dan virus. Masker N99 mampu memproteksi 99 mikropartikel di udara di bawah PM 2,5 dengan memiliki enam lapisan dan dua katup udara di sisi kanan dan kiri.

\section{d. Mencuci Tangan}

Salah satu upaya pencegahan virus COVID-19 atau COVID-19 adalah dengan rajin mencuci tangan secara detail dan menyeluruh. Hal ini karena virus COVID-19 menular lewat cairan tubuh yang keluar saat batuk atau bersin. Selain dapat tertular karena menghirup droplet saat berada dekat dengan orang yang terinfeksi, seseorang juga bisa 
tertular virus COVID-19 lewat tangan sebagai media penularan. Salah satu cara untuk mendukng upaya ini adalah dengan menjaga kebersihan pribadi, yaitu perilaku individu untuk menjaga kebersihan pribadi dalam kegiatan sehari- hari salah satunya dengan rajin dalam mencuci tangan. ${ }^{35}$ Sebagai contoh adalah ketika kita berjabat tangan dengan orang menutupi batuk dengan tangannya, atau ketika menyentuh objek yang terkontaminasi virus COVID-19. Itulah sebabnya, sangat penting untuk mencuci tangan menggunakan sabun dan air mengalir secara detail dan menyeluruh.

Mencuci tangan merupakan proses yang secara mekanis melepaskan kotoran dari kulit menggunakan sabun dan air mengalir untuk menghindari penyakit. Progam cuci tangan merupakan sarana kesehatan yang memiliki nilai murah dan dapat mengurangi kejadian risiko penyakit. ${ }^{36} \mathrm{Di}$ rumah sakit pun infeksi terkait perawatan kesehatan terjadi di seluruh dunia. Di negara berkembang, risiko terkait perawatan kesehatan lebih tinggi daripada negara maju sebagian besar infeksi ini menyebar dengan perantara satu pasien ke pasien yang lain oleh tangan petugas kesehatan. Kebersihan tangan adalah suatu istilah umum yang merujuk pada tindakan pembersihan tangan apa pun, hal ini dilakukan untuk upaya pengendalian penyebaran infeksi, kebersihan tangan berlaku untuk cuci tangan, cuci tangan antiseptic, gosok tangan berbasis alcohol. ${ }^{37}$ Mencuci tangan menggunakan sabun adalah salah satu upaya pencegahan dengan membersihkan tangan dan jari- jari menggunakan sabun dan air. Menurut Depkes RI, penyakit- penyakit yang dapat dicegah dengan cuci tangan pakai sabun yaitu; infeksi saluran pernafasan hal ini disebabkan karena dengan mencuci tangan menggunakan sabun dapat

${ }^{35}$ Satya Darmayani and Apita Ariyani, "Comparison The Number Of Bacteria Between Washing Hands Using Soap And Hand Sanitizer As A Bacteriology Learning Resource For Students," Indonesian Journal of Biology Education , vol. 3, no. 3, h. 258-65.

${ }^{36}$ Muhammadiyah Ibtidaiyah et al., "Penyuluhan Dan Manfaat Cuci Tangan Bagi Siswa Sekolah Dasar,” Journal of Community Dedication, vol. 1, no. 2, h. 2622-24.

${ }^{37}$ Alan P L Chan and Thomas Y K Chan, "Methanol as an Unlisted Ingredient in Supposedly Alcohol-Based Hand Rub Can Pose Serious Health Risk," Journal of Environmental Research and Public Health, 2018, 6-11, https://doi.org/10.3390/ijerph15071440. 
melepaskan virus- virus yang terletak di tangan dan permukaan telapak tangan. ${ }^{38}$

\section{Pengertian Sholat Berjarak}

Sebagai orang Islam, memiliki kewajiban dalam menjalankan ibadah sholat. Shalat merupakan ibadah secara vertikal yang langsung berkomunikasi antara makhluk (ciptaan) dengan Khaliknya (pencipta). Kita wajib melakukan shalat lima waktu dalam sehari. Di dalam shalat kita membaca tasbih ketika saat ruku' dan sujud. Belum lagi setelah salam (akhir shalat) kita banyak membaca dzikir atau wirid dengan memperbanyak bacaan tasbih, takbir, dan tahmid hingga 33 kali atau bahkan lebih. Jadi dengan melakukan shalat kita sudah bertasbih atau mengagungkan Allah, meskipun hanya dalam batasan ucapan saja.

Shalat merupakan pondasi bagi umat beragama Islam, jadi dapat dikatakan bahwa sebuah bangunan dapat berdiri kokoh dan kuat karena terdapat sebuah pondasi didalamnya. Dalam Bahasa Arab, shalat adalah berdoa, sedangkan dalam istilah shalat merupakan suatu ibadah wajib yang terdiri dari ucapan dan perbuatan yang diawali dengan takbiratul ikram dan diakhiri dengan salam. Apa maksud wajib? wajib secara bahasa artinya jatuh dan harus, sedangkan secara istilah apa-apa yang diperintahkan oleh Allah dengan bentuk keharusan, dan suatu hal yang wajib itu pelakunya diganjar jika ia melakukannya untuk mendapatkan pahala apabila dikerjakan dengan ikhlas, dan apabila orang yang meninggalkannya berhak mendapatkan adzab.

Shalat merupakan bagian dari iman, iman harus terdiri dari tiga unsur didalamnya yaitu keyakinan, ucapan dan amalan. Iman dapat meningkat dan dapat menurun, meningkat dengan ketaatan dan berkurang karena maksiat. Thaharah merupakan syarat sah shalat, rukun merupakan bagian dari sesuatu. Islam itu tidak cukup hanya dengan kepercayaan di hati saja, dan ditambah dengan ucapan 'laa ilaha illallah' di mulut, namun harus ada amalan. Sehingga akan

${ }^{38}$ Muara Angke et al., "Perilaku Cuci Tangan Pakai Sabun Studi Kualitatif Pada Ibu-Ibu Di Kampung Nelayan,” ARKESMAS, vol. 2, no. 1, h. 115-25. 
menjadikan permasalahan besar jika seseorang muslim tidak mempunyai amalan shalat. Secara umum shalat dibagi menjadi dua yaitu shalat fardhu dan shalat Sunnah. Shalat fardhu merupakan shalat yang hukumnya wajib, meliputi shalat shubuh, dhuhur, ashar, maghrib, isya'. Sedangkan shalat Sunnah merupakan shalat yang hukumnya Sunnah dan dianjurkan agar dikerjakan, diantaranya shalat tahajud, shalat dhuha, dan lain- lain. Shalat juga bisa dikerjakan dengan du acara, yaitu shalat munfarid atau shalat sendiri dan shalat berjamaah. Shalat munfarid dilakukan secara individu, Sedangkan shalat jamaah dikerjakan lebih dari satu orang, shalat jamaah diganjar dengan pahalah 27 kali derajat lebih banyak dibandingkan shalat sendiri.

Ada beberapa keutamaan mengerjakan ibadah shalat diantaranya: Shalat dapat mencegah seseorang dari perbuatan keji dan mungkar, Shalat termasuk amalan terbaik setelah dua kalimat syahadat, shalat bisa membersihkan dosa- dosa, shalat bisa menggugurkan dosa, shalat merupakan cahaya di dunia dan akhirat bagi orang yang melakukannya. Setelah mengetahui keutamaan shalat tersebut alangkah merugi jika ditinggalkan begitu saja.

\section{Shalat ketika Wabah COVID-19}

Setelah maraknya pandemi COVID-19, berdampak terhadap kegiatan yang ada di masjid salah satunya kegiatan ibadah shalat berjamaah. Didalam fikih kebencanaan, sesungguhnya bencana merupakan salah satu wujud Allah saying terhadap hambanya. Beraneka macam peristiwa yang menimpa manusia pada dasarnya merupakan sebuah ujian dan cobaan atas keimanan dan perilaku yang telah dilakukan oleh manusia, ${ }^{39}$ seperti saat ini kita sedang di uji dengan virus Covid- 19 peristiwa yang menimpa tersebut bukan lah persoalan, karena pada hakikatnya manusia hidup pasti terdapat ujian dari allah.

39 PP Muhammadiyah, Fikih Kebencanaan Tuntunan Shalat, (Yogyakarta: Pimpinan Pusat Muhammadiyah, 2018), h. 58-59. 
Ketika ada orang yang sakit terkena virus Covid- 19, hendaknya ia rela dengan apa yang telah menjadi ketetepan Allah dan harus bersabar atas apa yang telah ditakdirkannya, dan hendaknya berbaik sansgka terhadap Rabbnya, dan hendaknya orang tersebut senantiasa dalam kondisi antara takut akan azab Allah atas dosa yang dilakukannya, dan mengharap akan rahmat- Nya, separah apapun sakit yang ia rasakan, seseorang dilarang untuk mengharapkan kematian, sesungguhnya Allah menguji hambanya atas kadar kemampuan hambanya tersebut. Dan dianjurkan agar tidak melaksanakan sholat di masjid terlebih dahulu, karena orang tersebut rentan terhadap penyakit, dan ditakutkan akan menularkan penyakit yang ia bawa.

Dalam kondisi tersebarnya COVID-19 seperti yang sekarang sedang terjadi dan mengharuskan perenggangan social, dalam sholat lima waktu yang mena terdapat dalil untuk lurus dan rapatnya shaf shalat bahwa rasulullah sering mengingatkan jamaah ketika hendak sholat, agar shafnya lurus demi kesempuranaan dan tegaknya shalat tapi dalam keadaan darurat membolehkan suatu yang terlarang, Allah SWT berfirman: Tetapi barangsiapa dalam keadaan terpaksa (memakannya) sedang dia tidak menginginkannya dan tidak (pula) melampaui batas, maka tidak ada dosa baginya (QS Al Baqarah: 173).

Shalat lima waktu dimasjid berjarak beberapa ulama membolehkan untuk sholat dengan berjarak dalam suatu daerah, sedangkan apabila di daerah yang sudah rawan tertularnya virus Covid- 19 shalat lima waktu dilaksanakan di rumah masing-masing dan tidak perlu dilaksanakan di masjid, mushala, dan sejenisnya yang melibatkan banyak orang, agar terhindar dari mudarat penularan Covid- 19. Selain itu agama dijalankan dengan mudah dan sederhana, tidak boleh secara memberat- beratkan. Upaya dilakukanya sholat berjarak senantiasa agar jamaah terhindar dari tersebarnya virus COVID-19 ini, alangkah baiknya apabila suatu daerah telah banyak 
yang terkena COVID-19 melaksanakan ibadah sholat dilakukan dirumah masing-masing. ${ }^{40}$

Gambar 1.Pelaksanaan Sholat Jamaah Berjarak di Masjid.

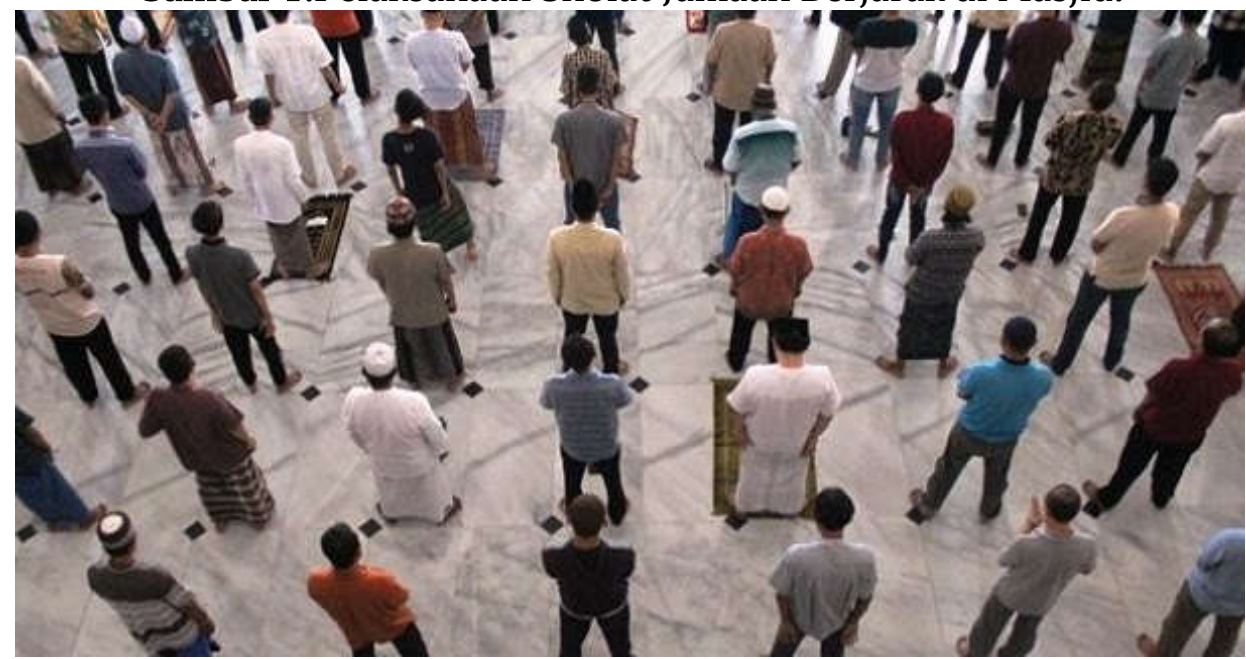

\section{Penutup}

Desember 2019 awal mulanya penyakit pandemic menyebar luas, virus dengan nama COVID-19 atau virus novel COVID-19 virus pertama kali diidentifikasi di kota Wuhan, Cina. Virus ini menyebar dengan sangat cepat hingga sudah mendunia. COVID-19 dapat merengut nyawa orang, telah banyak nyawa yang melayang diakibatkan COVID19 ini. Di Indonesia sendiri COVID-19 berdampak dalam hal perekonomian: berkurangnya jumlah wisman yang datang ke Indonesia, jamaah haji batal berangkat ke mekkah, harga barang menjadi mahal dan langka, di bidang peribadatan meminimalisir kegiatan dimasjid yang melibatkan banyak orang. Cara mencegahnya yaitu dengan melakukan lockdown di suatu daerah, melakukan social distancing, menggunakan masker ketika melakukan kegiatan diluar

${ }^{40}$ Pimpinan Pusat Muhammadiyah, Tuntunan Ibadah Dalam Kondisi Darurat COVID-19 (Yogyakarta: Muhammadiyah COVID-19 Command Center, 2020), h. 119-121. 
rumah, cuci tangan menggunakan sabun atau hand sanitizer setelah melakukan kegiatan, hal ini dilakukan dalam upaya pencegahan penularan COVID-19.

Di Indonesia dalam menjalankan ibadah sholat wajib untuk daerah yang masih aman dilaksanakan sholat dengan ketentuan berjarak hal ini dilakuka untuk mengantisipasi penyebaran Covid-19, dan di daerah yang rawan penularan Covid- 19 untuk sholat jama'ah dilakukan di rumah masing- masing agar terhindar dari mudarat penyakit Covid- 19. Dalam hal ini apabila di suatu daerah tertentu menjalankan ibadah sholat di masjid dengan shaf yang berjarak tidak termasuk kedalam bid'ah karena menurut ijtihad ulama, dan dalam upaya pencegahan virus Covid -19.

\section{Daftar Pustaka}

A Abidah, H N Hidaayatullaah, $\mathrm{R}$ M Simamora, D Fehabutar, L Mutakinati. "The Impact of Covid-19 to Indonesian Education and Its Relation to the Philosophy of "Merdeka Belajar." Studies in Philosophy of Science and Education, vol. 1, no. 1, 2020.

Adnan, Muhammad, Suliman Khan, Abeer Kazmi, Nadia Bashir, and Rabeea Siddique. "COVID-19 Infection : Origin , Transmission , and Characteristics of Human Coronaviruses." Journal of Advanced Research, vol. 24, 2020.

Akerlof, George A. "Social Distance and Social Decisions Author ( s ): George A . Akerlof Published by : The Econometric Society Stable URL : https://Www.Jstor.Org/Stable/2171877 to Econometrica." Jurnal of The Econometric Society, vol. 65, no. 5, 2020.

Al-mandhari, Ahmed, Dalia Samhouri, Abdinasir Abubakar, and Richard Brennan. "Coronavirus Disease 2019 Outbreak: Preparedness and Readiness of Countries in the Eastern Mediterranean Region.” East Mediterr Health Journal, vol. 26, no. 2, 2020.

Almuttaqi, A Ibrahim, Menteri Kesehatan, and Republik Indonesia. 
“Kekacauan Respons Terhadap COVID-19 Di Indonesia,” no. 13, 2020.

Angke, Muara, Jakarta Utara, Studi Kualitatif, and Intan Silviana Mustikawati. "Perilaku Cuci Tangan Pakai Sabun Studi Kualitatif Pada Ibu-Ibu Di Kampung Nelayan.” ARKESMAS, vol. 2, no. 1, 2017.

Barry, Mazin, Maha Al Amri, and Ziad A Memish. "Covid-19 in the Shadows of Mers-CoV in the Kingdom of Saudi Arabia.” Journal of Epidemiology and Global Health, vol. 10, no. 1, 2020.

BNPB. "Satuan Tugas Percepatan Covid-19 Indonesia." Pemerintah Republik Indonesai, 2020.

Chan, Alan P L, and Thomas Y K Chan. "Methanol as an Unlisted Ingredient in Supposedly Alcohol-Based Hand Rub Can Pose Serious Health Risk." Journal of Environmental Research and Public Health, 2018.

Chavez, Summer, Brit Long, Alex Koyfman, and Stephen Y Liang. "American Journal of Emergency Medicine Coronavirus Disease (COVID-19): A Primer for Emergency Physicians.” American Journal of Emergency Medicine, no. xxxx, 2020.

Corrigan, Patrick W, Annette Backs Edwards, Amy Qreen, Sarah Lickey Thwart, and David L Perm. "Prejudice, Social Distance, and Familiarity with Mental Illness.” Schizophrenia Bulletin, vol. 27, no. 2, 2001.

Darmayani, Satya, and Apita Ariyani. “Comparison The Number of Bacteria Between Washing Hands Using Soap And Hand Sanitizer As A Bacteriology Learning Resource For Students.” Indonesian Journal of Biology Education, vol.3, no. 3, 2017.

Febriana, Suyadi; Z Nuryana; N A. "The Fiqh of Disaster: The Mitigation of Covid-19 in the Perspective of Islamic EducationNeuroscience." International Journal of Disaster Risk Reduction IJDRR_2020 Article Inpress. 
Handayani, Astuti Budi, and Suyadi Suyadi. Relevansi Konsep Akal Bertingkat Ibnu Sina Dalam Pendidikan Islam Di Era Milenial. Ta'dibuna: Jurnal Pendidikan Islam. Vol. 8, 2019.

Ibtidaiyah, Muhammadiyah, M I Muhammadiyah, Rina Wijayanti Sagita, Rsud Wates, Kulon Progo, Jalan Tentara, Pelajar Km, and D I Yogyakarta. "Penyuluhan Dan Manfaat Cuci Tangan Bagi Siswa Sekolah Dasar." Journal of Community Dedication, vol. 1, no. 2, 2019.

Kharisma Noor Latifatul Mahmudah, Suyadi. “Akal Bertingkat Ibnu Sina Dan Taksonomi Bloom Dalam Pendidikan Islam Perspektif Neurosains." Edukasia Islamica: Jurnal Pendidikan Islam, vol. 5, no. $1,2020$.

Latha T, Anil K Bhat. “Compliance Towards Infection Prevention and Control Practices in Orthopedic Department of a Tertiary Care Hospital ." Journal of Health and Allied Sciences, vol. 18, no. 9, 2019.

Li, Peng, Ji-bo Fu, Ke-feng Li, Yan Chen, Hong-ling Wang, Jie-nan Liu, Yong-li Zhang, et al. "Transmission of COVID-19 in the Terminal Stage of Incubation Period: A Familial Cluster." Journal of Infectious Diseases, 2020.

Malik, Abdul. "Fungsi Komunikasi Antara Guru Dan Siswa Dalam Meningkatkan Kualitas Pendidikan (Studi Kasus Proses Belajar Mengajar Pada SMP Negeri 3 Sindue).” Jurnal Interaksi, vol. 3, no. $2,2014$.

Muhammadiyah, Pimpinan Pusat. Fikih Kebencanaan Tuntunan Shalat, 2018.

- - . Tuntunan Ibadah Dalam Kondisi Darurat Covid-19. Yogyakarta: Muhammadiyah Covid-19 Command Center, 2020. https://covid19.muhammadiyah.id/tuntunan-ibadah-dalamkondisi-darurat-covid19/. 
Peeri, Noah C, Nistha Shrestha, Siddikur Rahman, Zhengqi Tan, Saana Bibi, and Mahdi Baghbanzadeh. "The SARS, MERS and Novel Coronavirus (COVID-19) Epidemics, the Newest and Biggest Global Health Threats: What Lessons Have We Learned?” International Journal of Epidemiology, no. 0, 2020. https://doi.org/10.1093/ije/dyaa033.

Suyadi, Zalik Nuryana, Niki Alma Febriana Fauz. "The Fiqh of Disaster: The Mitigation of Covid-19 in the Perspective of Islamic Education-Neuroscience." International Journal of Disaster Risk Reduction, 2020.

Suyadi. "Diferensiasi Otak Laki-Laki Dan Perempuan Guru Taman Kanak-Kanak Aisyiyah Nyai Ahmad Dahlan Yogyakarta: Studi Pendidikan Islam Anak Usia Dini Perspektif Gender Dan Neurosains." Sawwa: Jurnal Studi Gender 13, no. 2, $2018 .$.

- - - “Kisah (Storytelling) Pada Pembelajaran Anak Usia Dini Dalam Kajian Neurosains Pendidikan Islam.” Jurnal Ilmiah Islam Futura 18, no. 1, 2018.

- - . “Konsep Akal Bertingkat Al-Farabi Dalam Teori Neurosains Dan Relevansinya Dengan Pendidikan Islam." Tawazun: Jurnal Pendidikan Islam, vol. 13, no. 1, 2020. https://doi.org/10.32832/tawazun.v13i1.2757.

- - . "Mainstreaming The Knowledge of Islamic Education With Progress and of Islam Nusantara Education." Akademika, vol. 24, no. 1, 2019.

- - . "Pendidikan Islam Anak Usia Dini Dalam Perspektif Neurosains: Robotik Akademik Dan Saintifik.” Edukasia: Jurnal Penelitian Pendidikan Isla, vol. 13, no. 2, 2018.

- - - Pendidikan Islam Dan Neurosains: Menelusuri Jejak Akal Dan Otak Dalam Al-Qur'an Hingg Pengembangan Neurosains Dalam Pendidikan Islam. Jakarta: Kencana, 2020. 
---. Teori Pembelajaran Anak Usia Dini Dalam Kajian Neurosains. Bandung: Remaja Rosdakarya, 2016.

- - . "The Synergy of Arts, Neuroscience, and Islam in Early Childhood Learning in Yogyakarta." TARBIYA: Journal of Education in Muslim Society 5, no. 1, 2018.

Suyadi, and Sutrisno. "A Genealogycal Study of Islamic Education Science at the Faculty of Ilmu Tarbiyah Dan Keguruan UIN Sunan Kalijaga.” Al-Jami'ah 56, no. 1, 2018.

Suyadi, Suyadi. "Hybridization of Islamic Education and Neuroscience: Transdisciplinary Studies of 'Aql in the Quran and the Brain in Neuroscience.” Dinamika Ilmu 19, no. 2, 2019.

- - . "Integration of Anti-Corruption Education (PAK) In Islamic Religious Education (PAI) With Neuroscience Approach (MultiCase Study in Brain Friendly PAUD: I Sleman Kindergarten Yogyakarta)." INFERENSI: Jurnal Penelitian Sosial Keagamaan 12, no. 2, 2019.

Telaumbanua, Dalinama. "Urgensi Pembentukan Aturan Terkait Pencegahan Covid-19 Di Indonesia.” Jurnal Pendidikan, Sosial, Dan Agama | 12, no. 1, 2020.

Widodo, Suyadi and Hendro. "Millennialization of Islamic Education Based on Neuroscience in The Third Generation University in Yogyakarta Indonesia.” Qudus International Journal of Islamic Studies 7, no. 1, 2019.

$\mathrm{Xu}$, Chunwen, Xilian Luo, Chuck Yu, and Shi-jie Cao. “The 2019-NCoV Epidemic Control Strategies and Future Challenges of Building Healthy Smart Cities,” 2020.

Yang, Li, and Zhang Lian-yang. “识》 解读” 45, no. 2, 2020.

Yunus, Nur Rohim, Annissa Rezki, Kebijakan Nabi, Muhammad Saw, Menangani Wabah, and Penyakit Menular. "Kebijakan Pemberlakuan Lockdown Sebagai Antisipasi Penyebaran Corona 
Muhammad Hisyam Fathin, Suyadi

Virus Covid-19.” Jurnal Sosial\&Budaya Syar-I 7, no. 3, 2020.

Zhou, Editor-in-chief Wang. The Coronavirus Prevention Handbook. Wuhan: Hubei Science and Technology, 2020. 